\title{
The Evolution Of Islamic Finance In Southeast Asia: The Case Of Malaysia
}

Rika Nakagawa, Institute of Developing Economies, Japan

\begin{abstract}
The purpose of this paper is threefold: to explain why the Islamic financial system was introduced in Malaysia; to outline how the Malaysian government has promoted this system; and to analyze the development of the Islamic financial system with a specific focus on the banking sector. In Malaysia, the first Islamic bank, Bank Islam Malaysia Bhd., was established in 1983. One turning point of the Islamic financial system in the country was the Financial Sector Master Plan presented by the central bank in 2001. The government, in accordance with the plan, has taken a strong initiative in the development of an Islamic financial system. As a result, the country has succeeded in promoting a comprehensive Islamic financial system, banking and insurance sectors and capital markets. In the banking sector, this paper reveals that the profit-sharing system does not seem to be popular in this country although the reward system is central to Islamic Finance. In order for further development of the Islamic financial sector, the reasons why the percentage of contracts under the profit-sharing system is small need to be analyzed.
\end{abstract}

Keywords: Islamic Finance in Malaysia, Financial Sector Master Plan, New Economic Policy, Bank Islam Malaysia Bhd., Islamic Banking Scheme

\section{INTRODUCTION}

$\mathscr{J}$ $\mathrm{n}$ the globalized economy, large amounts of capital are moving rapidly around the world. It is often pointed out that international capital flows have changed since September 11, 2001. The income of oil producing countries has increased due to a sharp increase in the price of oil; wealthy people in these countries are starting to consider how better to manage their money. Islamic financial products have become one of the sources for investments.

Islamic financial transactions are not new; Muslims have traded goods and services in accordance with Islamic concepts for a long time. However, it appears that the Nasser Social Bank which started business in Egypt in 1971 was the first institution that applied Islamic concepts to banking (Iqbal and Molyneux 2005, p. 37) ${ }^{(2)}$. Since that time, many Islamic financial institutions have been established not only in Islamic countries, but also in non-Islamic countries, such as the U.K.

Among Southeast Asian countries, Malaysia is at the forefront with regard to the introduction of Islamic Finance. Malaysia has promoted an Islamic financial system since 1983, when the Bank Islam Malaysia was established. Ten years after its establishment, the government started the Islamic Banking Scheme, which allowed banks to inaugurate Islamic banking in order to diffuse services throughout the country and to make the business environment more competitive. Due to this government policy, the number of banking institutions providing people with Islamic banking services has increased since that time.

The purpose of this paper is threefold: to explain why the Islamic financial system was introduced in Malaysia; to outline how the Malaysian government has promoted this system; and to analyze the development of 
the Islamic financial system with a specific focus on the banking sector.

The structure of this paper is as follows. The next section outlines the nature of Islamic Finance with some examples. The following section reviews how the Malaysian government introduced the Islamic financial system. The fourth section shows policies implemented in the development of the Islamic financial system and analyzes outcomes of promotion policies by utilizing statistical data. The final section consists of a summary and discussion of the future agenda for the Malaysian government for further development of the Islamic financial system.

\section{WHAT IS ISLAMIC FINANCE?}

It is necessary to have a basic understanding of the concept of riba in order to understand the principles of Islamic Finance in general and Islamic Finance as it has developed in Malaysia in particular. What follows is only a brief explanation of the concept of riba and the reader should understand that Muslim scholars do not agree on a single interpretation of riba. In addition, the description of Islamic law (Shariah), is extremely basic and does not touch upon the many areas of disagreement among Muslim scholars ${ }^{(3)}$.

\section{1-1. The Nature Of Islamic Finance}

\section{1-1-1. Prohibition Of Riba And The Rationale For Its Prohibition}

Some Muslim scholars consider that an ideal macroeconomy in Islam consists of four features: the prohibition of interest (riba), a principle of profit-sharing, the introduction of Islamic taxation (zakat), and an avoidance of wasteful use of resources (istaf) (Nomani and Rahnema 1994, p. 103).

There has been debate over riba in commercial transactions. According to Iqbal and Mirakhor (2007), riba is defined as a "premium" and contains four features (Iqbal and Mirakhor 2007, p. 56):

(1) it is positive and fixed ex-ante;

(2) it is tied to the time period and the amount on the loan;

(3) its payment is guaranteed regardless of the outcome or the purposes for which the principal was borrowed: and

(4) the state apparatus sanctions and enforces its collection.

In Islamic Finance, pre-determined return on capital is not permitted; however, remuneration is allowed in terms of social and economic justice. In addition, from the viewpoint of the function of money in the early period of Islamic economics, Muslim scholars put emphasis on money as a medium of exchange and a unit of account but did not regard money as a store of value. This idea was similar to the earlier Judeo-Christians views: that is, money by itself is "sterile" ${ }^{(4)}$. Muslims considered that money should not be utilized for the creation of money, but for business activities or other objectives. Therefore, pre-determined interest was considered as unjustified in an Islamic economy.

Riba (or riba al-buyu') is divided into two types: riba al-nasi'ah and riba al-fadl. Riba al-nasi'ah arises from money-to-money exchanges in which the lender requests an amount that is more than the principal amount when a borrower fails to pay back borrowed money to the lender on the due date. In an Islamic economy, an excess of repayment over the borrowed amount is strictly prohibited. Although this is called interest in a modern economy (Iqbal and Molyneux 2005, p.9), in Islam riba is considered a coercive and inappropriate measure. The other type of riba ( $r i b a$ al-fadl) means an excess value of goods received in trade under a barter system. Under this system, the principle is that goods exchanged must be of the same value. However, if one party receives goods of value greater than the value of goods provided to his/her trading partner, it is considered that the person received riba (riba al-fadl). One can regard riba al-fadl as very similar to income without labor or income from inappropriate transaction, such as fraud. 
From another viewpoint, riba is unconscionable due to an immediate claim for property rights. Property rights in Islamic society are considered to be of two types (Iqbal and Mirakhor 2007, p. 63):

(1) the property rights that are a result of the combination of an individual's labor and natural resources; and

(2) rights or claims to the property that is obtained through exchange, remittances of what Islam recognizes as the rights of those less able to utilize the resources to which they are entitled, outright grants, and inheritance.

Assets are obtained through either of them or both, and generate property rights. Money is recognized as a claim of property rights. Therefore, money lent is the transfer of property rights from a lender to a borrower, and the borrower's obligation is to return the rights and to pay back the money, which is equivalent to a loan. Payment of interest deviates from principles of property rights and violates Islamic values on these rights.

Venardos (2005) indicated five reasons for the prohibition of riba as the rationale for its prohibition. First, the interest-based system is against justice, a significant idea of Islam, because business activities are hindered by pre-determined interest. In general, it is impossible to predict perfectly that a project will succeed because of several risks or various unknown factors. The interest-based system forces entrepreneurs to pay the interest even if they fail in the project. This can be unfair in terms of the Islamic norm. Second, interest can be a disincentive for companies, in particular small and medium sized enterprises (SMEs), in promoting R\&D, adopting new technology, and expanding their business. Compared to large enterprises, SMEs hold fewer assets and depend on financial institutions for their financing. Because there is usually a great deal of uncertainty about an enterprise's future, SMEs cannot afford to spend much money for R\&D and experiments in new technology. In this sense, pre-determined interest has greater impact on SMEs than on large enterprises. Third, an interest-based banking system is interested in profitability and recovering capital of banks; ventures often have difficulty obtaining loans. Banks prefer a profitable project with less risk; there is no incentive for financial institutions to provide ventures with loans. Fourth, changes in interest rate affect investments. When interest rate rises due to conditions in the macroeconomic management, such as a high inflation rate or excess fiscal deficits, private investments are negatively affected. In the worst scenario, macroeconomic mismanagement can cause sudden outflows of capital and stagflation. The fifth reason is related to the above four reasons, the ex-ante interest leads to a security-oriented, not growth-oriented, economic system. Conventional financial institutions are under obligation to pay interest to depositors, they seek a safe return in lending. Therefore banks try to invest in certain projects to secure returns, such as projects of reliable and big companies, housing loans, government securities (Venardos 2005, pp. 47-48). Although not everyone agrees with these points, Venardos (2005) insists that these reasons imply that a "profit-sharing" system, instead of ex-ante interest, is consistent with Islamic values.

A "profit-sharing" system has two benefits to the economy. First, the system allows financial institutions to increase direct monitoring of the project. Under Islamic Finance, money should be utilized for projects appropriate from the viewpoint of religion, in other words, Islamic-compliant projects. Because Islamic banks are participants in the venture capital, it is much easier to observe the project. Second, Islamic banks can receive dividends if the project successfully earns profits. Thus, a partnership finance system is one principle of an Islamic economy.

\section{1-1-2. Principles of Shariah}

The other important factor of Islamic Finance is that financial transactions must be governed by Islamic law (Shariah). Shariah includes not only laws that people must follow, but also norms or things that are worth having or doing from the viewpoint of God (Nomani and Rahnema 1994, p. 2) ${ }^{(5)}$. Shariah consists of five practical aspects (Haron and Shanmugam 1997, p. 70);

(1) Fard or wajib: Compulsory duties and acts to be performed by all Muslims. Performance is rewarded and omission is punished; 
(2) Sunna, masnun, mandub, or mustahabb: Duties and acts that are recommended but not required. Performance of them is rewarded, but omission is not punishable;

(3) Ja'iz or mubah: Indifferent actions, whose performance or omission is neither rewarded nor punished;

(4) Makruh: Actions that are disapproved of but not punished or forbidden; and

(5) Haram: Actions that are both forbidden and punished.

Shariah is influenced by four factors; the Qur'an, the Hadith, the Ijma, and the Qiyas. The Qur'an, the most influential element for Shariah, is the holy book in which messages of God (Allah) to the Prophet were collected and provides Muslims with wide-ranging values for their lives. The Hadith complements the Qur'an and consists of reports of the sayings and actions of the Prophet while he was alive. The third source, the Ijma, means an agreement or a consensus among Muslim jurists with regard to a certain issue. The concept of consensus originated from the Hadith which stated, "My community will never agree upon an error" (Haron and Shanmugam 1997, p. 74). In order to avoid an "error", Muslim jurists put an emphasis on consensus, or Ijma. The fourth element is the Qiyas which means analogical reasoning. In some cases, because the Quran and Hadith are not clear about a particular case, Muslim jurists extend a former ruling to a new case using analogies between the present case and the former one.

Moreover, Ijtihad, a word derived from jahd, meaning to struggle or to strive in the sense of improving oneself, the community or society, is also an important concept. Jurists strive to derive fresh interpretations of various elements of Shariah consistent with and relevant to contemporary time ${ }^{(6)}$. Doi (1984) explains ijtihad as "an exercise of one's reasoning to arrive at a logical conclusion on a legal issue done by the Jurists to deduce a conclusion as to the effectiveness of a legal precept in Islam" (Doi 1984, p. 78). When Shariah does not provide clear guidance on modern problems, jurists are required to deduce rules that conform to the legitimacy of Islam from past consensus (Ijma), analogy (Qiyas), judicial preference, public interest, and customs (Iqbal and Mirakhor 2007, p. 13) $)^{(7)}$.

In Islamic Finance, all transactions must be compliant with the accepted meaning and interpretations of Shariah. This implies that Islamic financial institutions have to provide their services for Shariah-compliant activities; therefore, investments in Shariah non-compliant industries, such as a pork-producing or alcohol industries are strictly forbidden.

\section{1-2. Contracts Under Islamic Finance: Some Specific Illustrations ${ }^{(8)}$}

Iqbal and Mirakhor (2007) divide Islamic financial contracts into four types: (1)transactional contracts, (2)financing contracts, (3)intermediation contracts, and (4)social welfare contracts. Some contracts are transactions distinctly different from transactions found in conventional banking. For example, Musharakah belongs to (2) and (3) and means joint venture or partnership. Under this contract, Islamic banking institutions start a business with two or more persons. Because of the equal partnership, Islamic banks will be able to share profits and losses among partners (Figure 1). This concept is similar to equity investments in the modern economy. Mudharabah, which means profit-sharing, is under (3) (Figure 2). Transactions under this contract are similar to Musharakah in that Islamic financial institutions provide capital with their partners for a project. Islamic banks will thus be able to earn profits from the project; however, one difference between Musharakah and Mudharabah is that under a Mudharabah contract, Islamic banks must bear all losses.

The other contract, Murabahah (cost-plus sale) ${ }^{(9)}$ is a contract of the second type. Under Murabahah, an Islamic bank purchases goods on credit at the request of their customer. Then, the goods are sold to the customer at the purchased price plus the costs of the bank (presented as $\alpha$ in Figure 3). Murabahah is often utilized for purchasing durable goods, such as a computer or a car. Similarly, if the goods are purchased under a deferred payment sale, Bai' Bithaman Ajil is applied (Figure 4). This contract belongs to (1) and is often utilized for housing or automobile financing. 
In the case of Islamic bonds, bonds under Bai' Bithaman Ajil (deferred payment sale) or Ijarah (leasing) $)^{(10)}$ are often issued. In a Bai'Bithaman Ajil contract, a customer sells an asset, such as land or equipment, to a financier and receives payment. Next, the customer buys back the asset at a marked-up price from the financier and issues an Islamic bond with the marked-up price. The difference between the marked-up price that the financier sold for and the asset price that the customer sold for is the profit for the financier (Figure 4). In a contract of Ijarah, a customer sells an asset to a trustee designated by the customer. The trustee collects funds from investors and pays the amount of the asset to the customer. The asset owned by the trustee is leased to the customer until the end of the leasing period. The customer issues Islamic bonds to investors as evidence of the leasing contract and pays leasing fees to the trustee. At the end of the contract period, the trustee executes the put option requested by the customer to buy back the asset (Figure 5).

Figure 1. Musharakah Contract (joint venture)

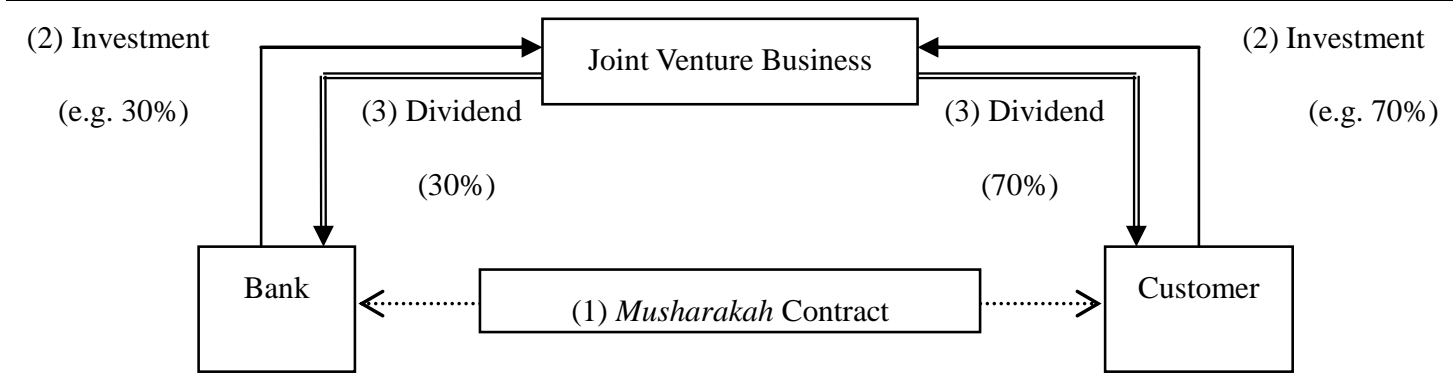

Source: Illustrated by the author.

Figure 2. Mudharabah Contract (profit-sharing)

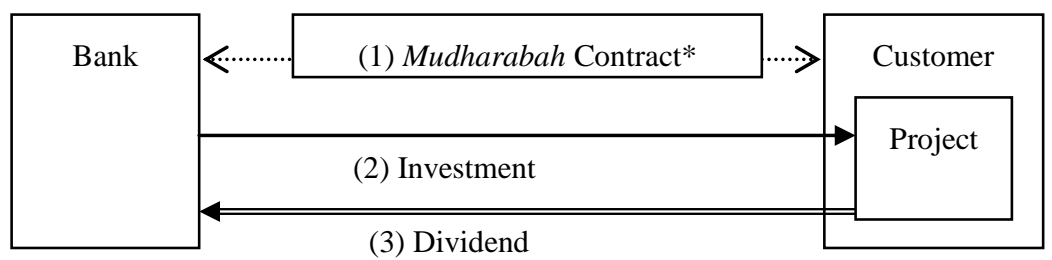

Note: *In a Mudharabah contract, an investor (bank) must bear all losses, if any.

Source: Illustrated by the author.

Figure 3. Murabahah Contract (cost plus)

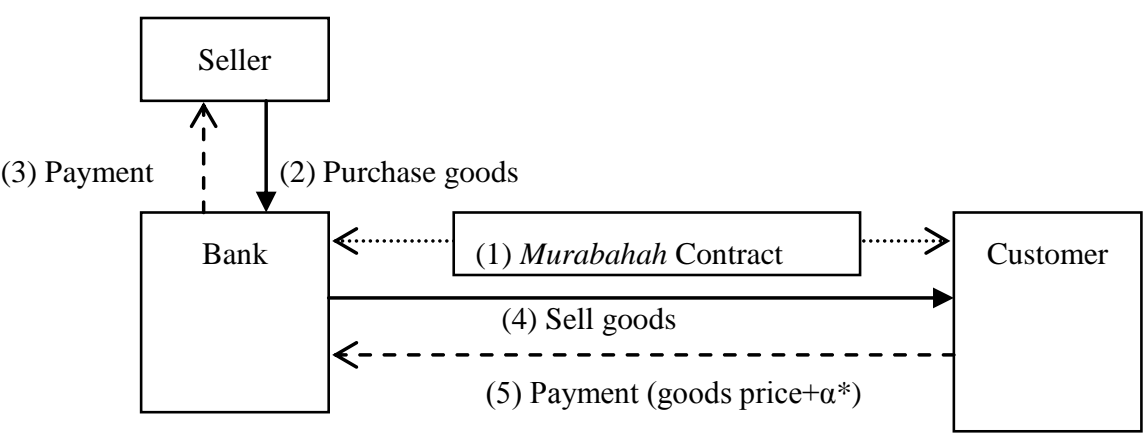

Note: $* \alpha=$ margin of the bank

Source: Illustrated by the author. 
Figure 4. Bai' Bithaman Ajil Contract

(2) Customer receives cash proceeds

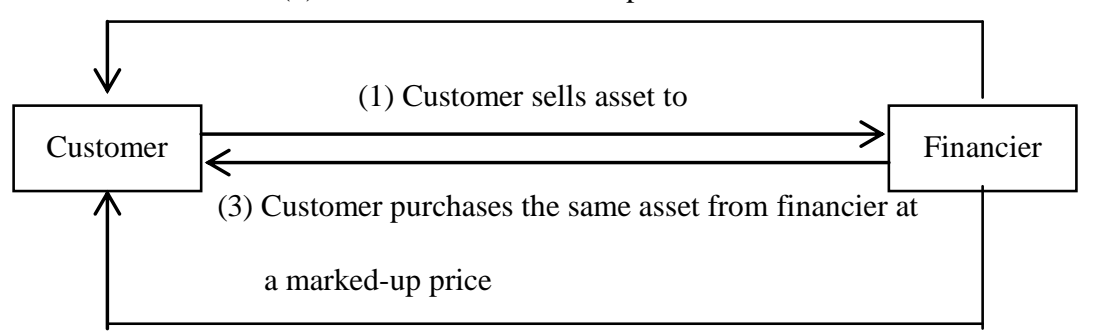

(4) Customer issues Islamic Securities with promise to pay financier the marked-up price

Source: Securities Commission (2003), p. 2-50.

Figure 5. Ijarah Contract

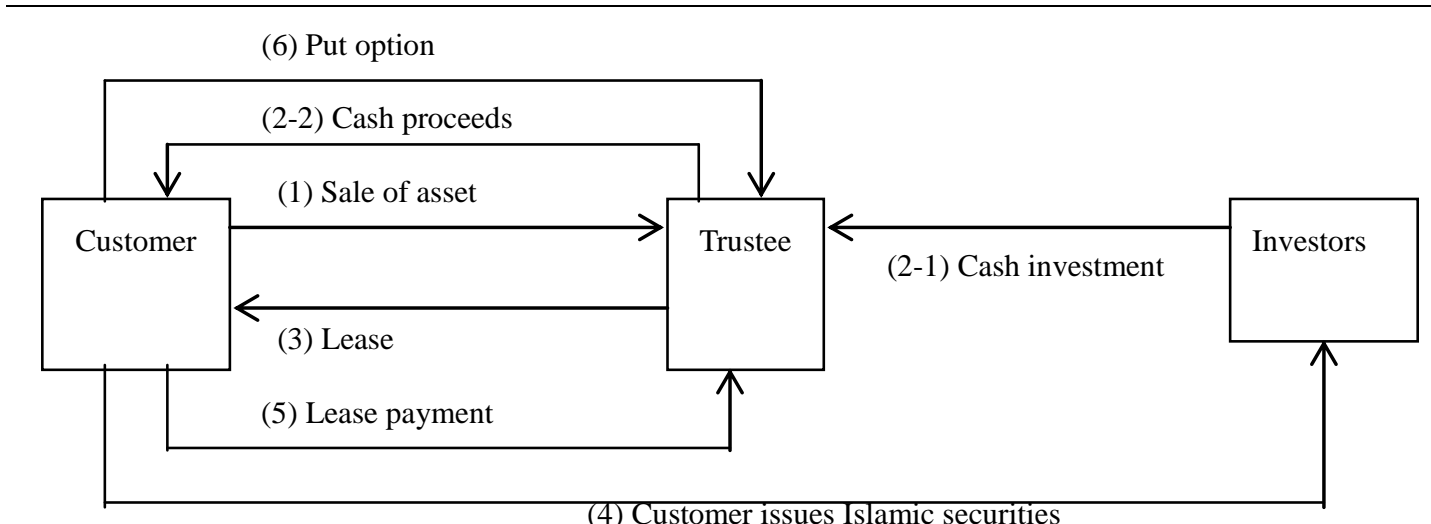

Source: Securities Commission (2003), p. 2:51.

As illustrated, the most outstanding feature of Islamic financial transactions is that they are reward-based and fee-based. These transactions are acceptable in the context of the prohibition of riba. In the reward-based system, Islamic banks can earn dividends after profits are fixed at the end of the project period. In other words, Islamic banks can share profits with their partners. As for the fee-based system, Islamic banks receive their service charges after the service is completed. In these transactions, Islamic financial institutions receive rewards or fees after they provide services; thus these transactions are compliant with Islamic values.

\section{AN INTRODUCTION OF ISLAMIC FINANCE IN MALAYSIA}

\section{2-1. The Background}

In Malaysia, there were many factors that led the government to decide to introduce an Islamic financial system. The riots that occurred in 1969 were one of the internal factors that led to an active discussion regarding this issue, followed by a set of government policies launched in 1971, the so-called New Economic Policy (Horii 1987, Torii 2003). As the riots were caused by income and wealth disparities between Malays and non-Malays, the government realized that balanced development should be the most significant element in a multi-ethnic country like Malaysia. For balancing economic development, the government announced two strategies: raising income and reducing absolute poverty by giving opportunities for employment, and achieving economic balances among ethnic groups $^{(11)}$. In particular, the government had to take relatively poor ethnic groups, including the Malays, the so-called Bumiputera $^{(12)}$, into consideration. 
As for external factors, in the 1970s the Islamic Resurgence movement arose in the Middle East. Another noteworthy event was the Iranian Revolution, known as the Islamic Revolution, in 1979. These occurrences influenced Muslims throughout the world and the voice and political power of Muslims within Malaysia also gradually increased ${ }^{(13)}$. Thus, the Malaysian government was required to manage the country with serious consideration toward Muslims.

\section{2-2. Factors Affecting The Establishment Of An Islamic Bank}

Due to the pressures of Islamic political groups, the government understood the importance of Islamic values and considered applying those values to social and economic systems within the country. In 1980, the government held a meeting to discuss significant issues with regard to the introduction of an Islamic financial system $^{(14)}$. During the next year the government set up the National Steering Committee on Islamic Finance under the initiative of the Central Bank, Bank Negara Malaysia. After a one-year study by this committee, the results were submitted to the government and provided the government with supportive opinions for the establishment of an Islamic bank. Based on this study, the government decided to legislate an Islamic financial system into existence. In 1983, the government enacted the Islamic Banking Act 1983 and Bank Islam Malaysia Bhd. (BIMB) was established $^{(15)}$.

There are two different views with regard to why the Malaysian government was so positive about the introduction of the Islamic financial system in the country. The Central Bank indicated that the government was merely responding to the strong needs of Muslims. (Bank Negara Malaysia 1983, p 16). The other view, presented by Torii (2003), stated that it was due to the strategic efforts of "Islamization" promoted by Dr. Mahathir, former Prime Minister. According to Torii, the government intended to involve Muslims in the process of economic development. This may be related to the savings rate of Muslims. It was often said that the savings rate of Muslims particularly in rural areas, was not high (Zakariya 1988, p. 86). Several reasons have been considered: their customs, religion, or unfavorable location of banks. However, for whatever reason, the government needed to take action to promote the national savings of Muslims. For the government, savings were essential to build a basic infrastructure and stimulate economic activities in the private sector and also to achieve the government's overall goal of becoming a developed country. If Muslims were avoiding making deposits into their accounts in conventional banks because these banks were under the interest-based system, the most effective way to improve savings was the establishment of an Islamic bank ${ }^{(16)}$.

\section{THE DEVELOPMENT OF THE ISLAMIC FINANCIAL SYSTEM}

\section{3-1. The Development of the Islamic Financial System}

Malaysia has enjoyed stable development of a comprehensive Islamic financial system for banking, capital market, and insurance ${ }^{(17)}$. The banking sector, in particular, has developed rapidly under strategic government policies.

One policy which accelerated the development of the Islamic banking system was the Islamic Banking Scheme in 1993. The government allowed conventional banking institutions to begin Islamic banking. As a result, by 1998 the number of banking institutions offering Islamic banking services increased. As shown in Table 1, in 1993, 20 banking institutions started Islamic banking services: 11 commercial banks, seven finance companies, and two merchant banks. In 1998, the total number of conventional banking institutions offering Islamic services increased to 48 with 10 branches and 2,382 Islamic counters. In 2006, the number of non-Islamic banking institutions and counters had decreased to 25 and 927 respectively due to the restructuring process after the currency crisis of 1997. The number of conventional banks offering Islamic banking services was affected by the restructuring program of the Central Bank after the crisis.

On the other hand, it is noteworthy that Islamic banks expanded branches rapidly after the crisis. From 1998 to 2006, in the first four years the number of branches increased from 80 to 128; however, in the second four 
years there was a very large increase to 1,161 branches. The services of Islamic banks were now diffused throughout the country.

Table 1

Number of Banks Offering Islamic Banking Services

\begin{tabular}{|c|c|c|c|c|c|}
\hline & 1983-92 & 1993 & 1998 & 2002 & $2006^{1}$ \\
\hline Banking Institution & 1 & 21 & 49 & 36 & 27 \\
\hline Commercial Banks & 0 & 11 & 25 & 8 & 14 \\
\hline Finance Companies & 0 & 7 & 18 & 0 & 10 \\
\hline Merchant Banks & 0 & 2 & 5 & 4 & 3 \\
\hline Islamic Banks & 1 & 1 & 1 & 9 & 2 \\
\hline Discount Houses & 0 & 0 & 0 & 6 & 7 \\
\hline Counter & n.a. & n.a. & 2,382 & 2,065 & 927 \\
\hline Commercial Banks & n.a. & n.a. & 1,553 & 1,335 & 909 \\
\hline Finance Companies & n.a. & n.a. & 823 & 730 & 9 \\
\hline Merchant Banks & n.a. & n.a. & 6 & 0 & 9 \\
\hline Branch & n.a. & n.a. & 90 & 138 & 1,171 \\
\hline Commercial Banks & n.a. & n.a. & 7 & 8 & 10 \\
\hline Finance Companies & n.a. & n.a. & 3 & 2 & 0 \\
\hline Islamic Banks & n.a. & n.a. & 80 & 128 & 1,161 \\
\hline
\end{tabular}

Note: 1 . As of the end of June 2006.

Source: Bank Negara Malaysia, web site (http://www.bng.gov.my <last cited on April 18, 2007>)

One turning point for the Malaysian Islamic banking sector was the Asian Currency Crisis of 1997, which severely affected the financial sector. This experience led the government to help the sector develop as a more resilient industry. In 2001, the Central Bank published the Financial Sector Master Plan (FSMP) in which several policies for the sector's development were presented ${ }^{(18)}$. One objective of the FSMP was to promote a more efficient and resilient financial sector. The FSMP provided development policies not only for the conventional banking sector but for the Islamic banking sector. First, the Central Bank set $20 \%$ as a target share of the Islamic banking sector which must be achieved by 2010. Toward this, the Central Bank set a target each year which rose gradually $^{(19)}$. In 2004, Bank Negara Malaysia announced that they would give Islamic banking licenses to three foreign banks. After a considerable screening process, three banks from Middle Eastern countries obtained licenses and started their business: Al Rajhi Banking \& Investment Corporation (Malaysia) Bhd., Kuwait Finance House (Malaysia) Bhd., and Asian Finance Bank Bhd ${ }^{(20)}$. Furthermore, in 2005 the Central Bank stated that conventional domestic banks were able to obtain full-fledged Islamic banking licenses. In response to this, some leading banks opened full-fledged Islamic banking offices.

As the Islamic banking system has developed, services offered by Islamic banks and banking institutions under Islamic Banking Scheme have become diversified (Table 2). Islamic banking services are very similar to those in conventional banks; however, some distinct differences can be observed. For example, current accounts and savings accounts are under Wadiah Yad Dhamanah (deposits with guarantee), Mudharabah (profit-sharing), and Qard (interest-free loan); depositors are guaranteed repayment of the whole amount of deposits and have no right to receive any return from Islamic banks. Islamic banks, however, may provide depositors with returns as gratitude because of the other concept of Mudharabah. In the case of investment accounts, money in a general investment account under Mudharabah (profit-sharing) and Qard (interest-free loan) is for an Islamic bank to invest in projects without instruction from depositors, whereas depositors with special or specific investment accounts under Mudharabah (profit-sharing) are able to instruct the bank as to which project to invest in. 
Table 2. Islamic Banking Services in Malaysia and the Concept of Shariah

\begin{tabular}{|c|c|c|}
\hline Product Name in General & Islamic Banking Products & The Concept of Shariah Used \\
\hline \multirow[t]{3}{*}{ Deposit } & current account-i & Wadiah Yad Dhamanah, Mudharabah, Qard \\
\hline & savings account-i & Wadiah Yad Dhamanah, Mudharabah, Qard \\
\hline & commodity Murabahah-i & Murabahah / Tawarruq \\
\hline \multirow[t]{3}{*}{ Investment } & general investment account-i & Mudharabah, Qard \\
\hline & special investment account-i & Mudharabah \\
\hline & specific investment account-i & Mudharabah \\
\hline \multirow[t]{35}{*}{ Financing } & asset financing-i & Tawarruq / Murabahah, Mudharabah \\
\hline & & Musharakah, Ijarah \\
\hline & asset-backed financing-i & Ijarah \\
\hline & benevolent loan-i & Qard \\
\hline & block discounting-i & Bai’ Dayn \\
\hline & bridging finance-i & Istisna', Bai' Bithaman Ajil \\
\hline & bungalow lots financing-i & Bai’ Bithaman Ajil \\
\hline & cash line facility-i & Bai’ Inah, Bai' Bithaman Ajil, Murabahah \\
\hline & club membership financing-i & Bai' Bithaman Ajil \\
\hline & Commodity Murabahah Financing-i & Murabahah, Tawarruq \\
\hline & computer financing-i & Bai’ Bithaman Ajil \\
\hline & contract financing-i & Murabahah, Bai’ Bithaman Ajil, Istisna', \\
\hline & & Musharakah, Mudharabah, Ijarah \\
\hline & education financing-i & Murabahah, Bai' Bithaman Ajil, Bai' Inah \\
\hline & equipment financing-i & Bai’ Bithaman Ajil \\
\hline & factoring facility-i & Bai’ Dayn \\
\hline & fixed asset financing-i & Bai’ Bithaman Ajil \\
\hline & floor stocking financing-i & Murabahah, Bai’ Bithaman Ajil \\
\hline & hire purchase agency-i & Wakalah \\
\hline & home/house financing-i & Bai’ Bithaman Ajil, Istisna’, \\
\hline & & Variable Rate Bai' Bithaman Ajil \\
\hline & industrial hire purchase-i & Ijarah \\
\hline & land financing-i & Bai’ Bithaman Ajil \\
\hline & leasing-i & Ijarah \\
\hline & pawn broking-i & Rahnu (Qard and Wadiah Yad Dhamanah) \\
\hline & & Rahnu (Qard) \\
\hline & personal financing-i & Bai' Bithaman Ajil, Murabahah, Bai’ Inah \\
\hline & plant \& machinery financing-i & Bai’ Bithaman Ajil, Istisna, Ijarah \\
\hline & project financing-i & Bai’ Bithaman Ajil, Istisna, Ijarah, \\
\hline & & Musharakah, Mudharabah, \\
\hline & & Tawarruq / Murabahah \\
\hline & property financing-i & Bai’ Bithaman Ajil, Istisna, \\
\hline & & Variable Rate Bai' Bithaman Ajil \\
\hline & revolving credit facility-i & Bai' Bithaman Ajil, Murabahah, Hiwalah, Bai' Inah \\
\hline & share financing-i & Bai’ Bithaman Ajil, Bai’ Inah \\
\hline
\end{tabular}


Table 2. Islamic Banking Services in Malaysia and the Concept of Shariah (Continued)

\begin{tabular}{|c|c|c|}
\hline Product Name in General & Islamic Banking Products & The Concept of Shariah Used \\
\hline \multirow[t]{11}{*}{ Financing } & shop house financing-i & Bai’ Bithaman Ajil, Istisna', \\
\hline & & Variable Rate Bai’ Bithaman Ajil \\
\hline & sundry financing-i & Bai' Bithaman Ajil \\
\hline & syndicated financing-i & Istisna', Bai’ Bithaman Ajil, Ijarah \\
\hline & term financing-i & Bai’ Bithaman Ajil, Variable Rate Bai' \\
\hline & & Bithaman Ajil \\
\hline & tour financing-i & Bai’ Bithaman Ajil \\
\hline & umrah \& visitation financing-i & Bai' Bithaman Ajil \\
\hline & vehicle/automobile financing-i & Ijarah, Bai' Bithaman Ajil, Murabahah \\
\hline & working capital financing-i & Murabahah, Bai’ Bithaman Ajil, Tawarruq / \\
\hline & & Murabahah, Musharakah, Mudharabah \\
\hline \multirow[t]{7}{*}{ Trade Finance } & accepted bills-i & Murabahah, Bai' Dayn \\
\hline & bank guarantee-i & Kafalah \\
\hline & bills of exchange-i & Wakalah \\
\hline & export credit refinancing-i & Murabahah, Bai' Dayn \\
\hline & letter of credit-i & Wakalah, Murabahah, Ijarah, Bai' Bithaman Ajil \\
\hline & shipping guarantee-i & Kafalah \\
\hline & trust receipt-i & Wakalah, Murabahah \\
\hline \multirow[t]{3}{*}{ Card Services } & charge card-i & Qard \\
\hline & credit card-i & Bai’ Inah, Bai’ Bithaman Ajil \\
\hline & debit card-i & Ujr \\
\hline
\end{tabular}

Note: 1 . This table lists only major products and may be updated by Bank Negara Malaysia from time to time.

2. For the meaning of each Shariah concept, see Appendix.

3. '-i' in the table means "Islam".

Source: Bank Negara Malaysia, web site. (http://www.bnm.gov.my/index.php?ch=174\&pg=467\&ac=370 <last cited on July 18 , 2008>)

Not only did the government make every effort by implementing policies, but implicit supports were also important in the development of the Islamic banking sector. The government holds deposits in the Islamic banking sector and before 2000, the share of deposits by the government was relatively large. As time passed and Islamic Finance became more popular, shares of deposits by business enterprises and individuals gradually increased (Figure 6). 
Figure 6. Deposits by Holders in Banks Offering Islamic Banking Services
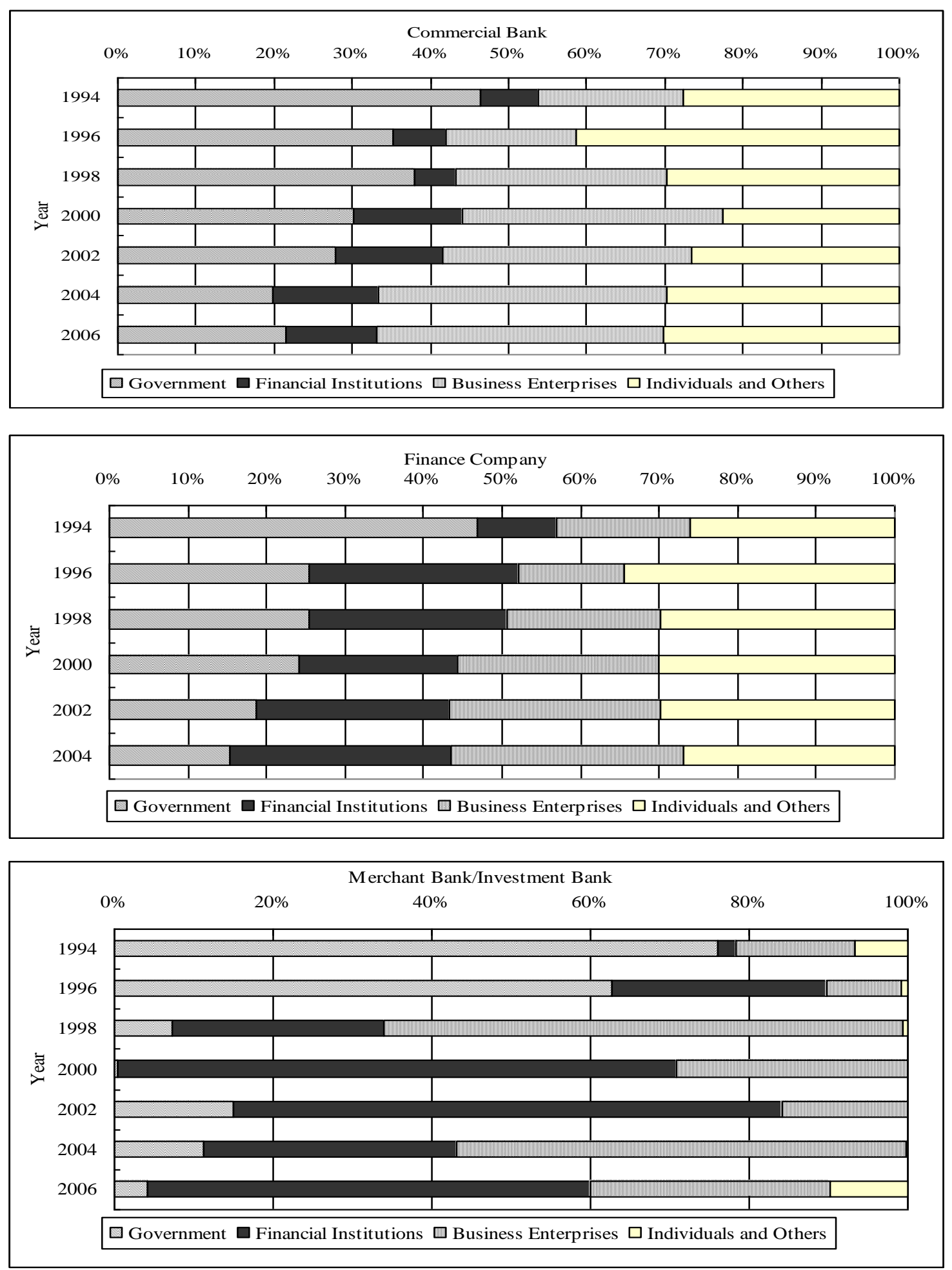

Note: Finance company data is shown only until 2004 because all finance companies had merged with commercial banks by the end of 2005.

Sources: Bank Negara Malaysia, Monthly Statistical Bulletin, various issues. 
In the case of Islamic capital markets, the government decided upon tax incentives with regard to the issuance of Islamic securities. In 2003 tax treatments were announced that stated that the sale and resale of assets between a party and a financier (or a Special Purpose Vehicle, SPV) were not deemed as sales for income tax; gains from the disposal of Islamic Securities by investors were exempted from real property tax gains; stamp duty was also exempted on the instrument of transfer of assets by the party seeking financing to the SPV; and so on (Securities Commission 2003, p. 2:52) ${ }^{(21)}$. These policies contributed to an expansion of Islamic capital markets in Malaysia. In the public sector, in 1990 the capital raised by new issues of Government Islamic bonds, the Government Investment Issues, was only RM300 million which increased to RM4 billion by 2005; however, the government share of new issues of debt securities was only $11.5 \%$ in 2005 . On the other hand, the private sector raised more funds through the Islamic capital market. In 1990, new issues of Islamic bonds by the private sector were RM378.5 million; however, they increased to RM9.5 billion by 2005. Although the ratio of new issues of Islamic bonds to those of total debt securities decreased from $14.5 \%$ in 1990 to $6.5 \%$ in 1995 , the ratio became $25.0 \%$ in 2000 and 2005 (Table 3).

Table 3. New Issues of Islamic Bonds (RM million)

\begin{tabular}{lrrrr}
\hline & $\mathbf{1 9 9 0}$ & $\mathbf{1 9 9 5}$ & $\mathbf{2 0 0 0}$ & $\mathbf{2 0 0 5}$ \\
\hline Public Sector & & & & \\
(1) Government Investment Issues & 300.0 & 750.0 & $2,000.0$ & 4000.1 \\
(2) New Issues of Debt Securities & $5,440.6$ & $2,750.0$ & $14,975.4$ & $34,687.9$ \\
Ratio of (1) to (2) (\%) & 5.5 & 27.3 & 13.4 & 11.5 \\
\hline Private Sector & & & $7,666.1$ & $9,537.0$ \\
(3) Islamic Bonds & 378.5 & 800.0 & $38,196.1$ \\
(4) New Issues of Debt Securities & $2,602.7$ & $12,222.7$ & $30,395.1$ & 25.2 \\
\hline Ratio of (5) to (6) (\%) & 14.5 & 6.5 & 25.0 \\
\hline
\end{tabular}

Source: Bank Negara Malaysia (2007)

\section{3-2. Some Noteworthy Findings And Discussion Of Islamic Finance In Malaysia}

As has been noted in the last section, the Malaysian government did not permit other banking institutions entry into the Islamic banking market in the early stages of the Islamic banking system. After the government realized BIMB could survive in the country, they introduced the Islamic Banking Scheme and allowed conventional banks to offer Islamic banking services. The government expected BIMB to focus on the development of Islamic banking and create many financial products acceptable to the Malaysian people, in particular Muslims (Bank Negara Malaysia 1999, p. 244). It would seem that the government protected BIMB and encouraged its banking business because it was in its infancy.

Even after the Islamic Banking Scheme, the government continued to give unofficial support to banking institutions. As shown in Figure 5, from 1994 to 1999 percentages of deposit by the government ranged from 20\% to $50 \%$. The government took a strong initiative in promoting Islamic Finance and supporting the Islamic banking sector by setting a target, of $20 \%$ by 2010 . This target is an obligation for banking institutions to achieve; however, it is impossible to successfully reach the target unless banks have enough deposits. Therefore, there is no question that the government provided deposits in addition to official encouragement particularly in the early stage of development.

With regard to financing activities, Table 4 clearly shows that the actual situation is different from theory. In section 1, it was explained that theoretically "profit-sharing" is one feature of Islamic Finance; however, financing under profit-sharing contract, Mudharabah, is extremely small. Financing under joint venture, Musyarakah, is less than $1.4 \%$. In contrast, large portions of financing were provided under a Bai Bithaman Ajil contract. 
This reality implies that Islamic banks tend to avoid Musyarakah (joint venture) and Mudharabah (profit-sharing) due to a number of reasons. One possibility is these contracts are very similar to an equity investment in the context of non-Islamic Finance. In other words, Islamic financial institutions are playing the role of investment banks in the economy. For investment banks, collecting reliable information about the profitability or feasibility of a project or business of a company in which the investment banks are planning to invest is critical in order to get the best return on their investments. Therefore, Islamic banks need to access reliable information when they offer finance under a Musyarakah or Mudharabah contract. In particular, under a Mudharabah contract Islamic banks must bear all losses that result from failure of the investment; thus it is very natural for Islamic banks to take a prudent attitude. The statistics regarding contracts imply that there are critical problems for Islamic banks in collecting enough information; this has resulted in a small share of financing by these contracts.

Table 4. Financing by Contract (Share, \%)

\begin{tabular}{cccccccccc}
\hline & $\begin{array}{c}\text { Bai } \\
\text { Bithaman } \\
\text { Ajil }\end{array}$ & Ijarah & $\begin{array}{c}\text { Ijarah } \\
\text { Thumma } \\
\text { Al-Bai }\end{array}$ & Murabahah & Musyarakah & Mudharabah & Istisna' & Others & Total \\
\hline $\mathbf{2 0 0 1}$ & 48.3 & 4.3 & 22.2 & 7.0 & 1.4 & n.a. & 0.9 & 15.9 & 100.0 \\
$\mathbf{2 0 0 2}$ & 49.2 & 3.0 & 23.3 & 7.3 & 0.7 & 0.0 & 1.3 & 15.3 & 100.0 \\
$\mathbf{2 0 0 3}$ & 47.7 & 1.4 & 27.6 & 6.2 & 0.5 & 0.1 & 0.6 & 15.9 & 100.0 \\
$\mathbf{2 0 0 4}$ & 49.9 & 0.9 & 23.2 & 7.0 & 0.4 & 0.1 & 1.2 & 17.4 & 100.0 \\
$\mathbf{2 0 0 5}$ & 40.7 & 0.7 & 31.0 & 6.9 & 0.3 & 0.0 & 0.9 & 19.6 & 100.0 \\
\hline
\end{tabular}

Source: Bank Negara Malaysia, web site (http://www.bnm.gov.my <last cited on April 20, 2007>)

\section{CLOSING REMARKS: THE FUTURE AGENDA FOR ISLAMIC FINANCE IN MALAYSIA}

This paper reviewed the development of Islamic Finance in Malaysia. As has been noted, the government has taken a strong initiative in the development of an Islamic financial system. The government set a target share to be achieved by 2010 in the Financial Sector Master Plan, so the Islamic financial sector is expected to develop even further. Moreover, the government implemented preferential tax treatments for the Islamic financial sector. As a result, Malaysia has succeeded in promoting a comprehensive Islamic financial system, banking and insurance sectors and capital markets. However, in order to promote stable development of the Islamic financial sector, there are some problems that need to be solved. The Islamic financial sector needs more professionals who have balanced knowledge regarding both Islamic concepts and financial technologies. Malaysia has established an educational institution to train experts in Islamic Finance; however, the number of professionals is still insufficient. Human resource development is an urgent issue for Malaysia. Secondly, the reasons for the share of contracts under the profit-sharing system being small need to be analyzed. As section 1 shows, the profit sharing system is central to the Islamic economy; however, this reward system does not seem to be popular. The question is whether the Islamic financial system itself has flaws or whether there are institutional problems within Malaysia. One possibility is that asymmetric information exists in the Islamic financial market which leads Islamic banks to be risk averse and to avoid reward-system lending. If that is the case, a more transparent-information providing system is needed. In order to understand the Malaysian Islamic financial system better, further study on this issue is needed.

\section{NOTES}

(1) An earlier version of this paper was presented at the 2007 Applied Business Research Conference, where it received the Best Paper Award. I would like to thank an anonymous JABR referee and Susan Tennant for their helpful comments that immensely improved this paper.

(2) Some articles state that the Mit Ghamr, established in Egypt in 1963, was the first savings bank with Islamic values; however, it lasted only four years (for example, Iqbal and Mirakhor 2007, p. 24). Some other articles considered the Nasir Social Bank that followed to be a modern banking institution with Islamic principles.

(3) There is controversy among Muslim scholars as to what is riba is or is not and also what the nature of Shariah is and how Shariah should be interpreted. Some Muslim scholars disagree with the idea that riba is interpreted as interest. Rahman (1964) presented controversies over interpretations of Riba in conventional banking and stated that riba did not mean interest in 
contemporary banking. Farooq (2006) raises a question about "riba-interest equivalence" and criticizes many studies on the grounds that the presumption that riba is equivalent to interest, which provides the rationale for the prohibition of interest, is incorrect. Farooq (2006) states that some scholars have translated riba as usury, not interest. Iqbal and Mirakhor (2007) mentioned that about four thousand years ago usury was considered as the practice of lending money with interest. It was disapproved of on moral, religious, and legal grounds. In 2002, the BBC reported that the Al-Azhar Institute in Egypt, one of the most prestigious institutions of Islamic Studies, supported fixed interest rates in financial business (http://news.bbc.co.uk/2/hi/business/2488525.stm, cited on July 10, 2008). Furthermore among various religious traditions, such as Hinduism, Buddhism, Judaism, Christianity, and Islam, explicit and implicit prohibition of interest is mentioned (Iqubal and Mirakhor 2007, p. 69). Ahmad (1981) mentions the historical debates on riba and interest in which all three monotheistic religions (Judaism, Christianity, and Islam) have engaged. For readers who wish to delve more deeply into riba and Shariah, please read Rahman(1964), Ahmad (1981), Noorzoy (1982), Rashid (1983), Doi (1984), Mohamed (1988), Ahmad (1993), Grossman (2002), Farooq (2006), Iqubal and Mirakhor (2007) etc. I thank the referee for pointing me to this literature.

${ }^{(4)}$ I would like to thank the referee for this insight.

${ }^{(5)}$ For more information of the controversies surrounding the meaning and contemporary interpretations of Shariah, please read Khan (1999) and Kuran (2004).

(6) The word jihad is also derived from jahd and its meaning is very similar to jahd, not necessarily a religious war. For more information of this subject, please visit Muqtedar Khan's Column on Islam and Global Affairs (www.ijtihad.org), The Other Malaysia (www.othermalaysia.org), and International Centre for Islam and Pluralism (www.icipglobal.org). I would like to thank the referee for raising this point.

(7) Ijtihad is sometimes incorporated within the meaning of Ijma and Qiyas (Haron and Shanmugam 1997, p. 71).

(8) This section illustrates some of the contracts; however, there are many types of Islamic contracts. As for other contracts, please see Appendix. For more details, see Haron and Bala (1997), Lewis and Algaoud (2001), Iqbal and Llewellyn (2002), Iqbal and Mirakhor (2007) etc.

(9) This is sometimes called "mark-up" instead of "cost plus". In some countries, Islamic banks refer to this as service charges.

${ }^{(10)}$ In the early stages of development of the Islamic bond market, Malaysia started to issue Islamic bonds under these two concepts. As of 2006 many types of Islamic securities had been developed and various concepts of Shariah had been applied to Islamic bonds.

${ }^{(11)}$ For more details, see the website of the Economic Planning Unit (http://www.epu.jpm/my).

${ }^{(12)}$ The word, Bumiputera, was originally from the Malay language and combines two words, bumi (soil) and putera (son). The government defines Bumiputera as the Malays and the other indigenous people living in Sabah and Sarawak, for example, Melanau, Dayak, Kadazan-Dusun, Bajau and other native ethnic groups which are listed in the Federal Constitution (Mason and Omar 2003, p. 2).

${ }^{(13)}$ This is called the Dakwa movement. For details, see Chandra (1987) and Shamsul (1997).

(14) This meeting was called the Bumiputera Economic Congress and supervised by the largest political party, the United Malays National Organization (UMNO).

(15) In the same year, the government also enacted the Government Investment Act 1983 and issued Government Investment Issues (GIC) with Islamic concepts (interest-free). In Malaysia, banks have to hold liquid assets in accordance with banking regulations. Government bonds are the most popular liquid assets for banks. Islamic banks, however, cannot purchase Government bonds because they are not interest-free. In order to solve this problem, the Malaysian Government launched the GIC.

(16) Although Malaysia is a multi-ethnic country, Malaysia successfully introduced an Islamic financial system and no problems occurred with respect to other ethnic groups. For one reason, the Islamic financial system in Malaysia is very open to the public, and there is no religious limit. In reality, Chinese banks provide Islamic banking services and many Chinese utilize those services. Some Muslims, on the other hand, prefer conventional banking services and do not utilize Islamic banking services. The government intends the development of dual financial systems in Malaysia in order for companies and consumers to increase sources of financing as well as to enhance alternative measures for saving for Muslims,

(17) This is called takaful.

(18) Soon after the crisis, the Central Bank raised the interest rate to stop further depreciation of their currency. Borrowers in conventional banking suffered under the tight monetary policy which resulted in an increase in non-performing loans for conventional banks. On the other hand, people financed by Islamic banking institutions suffered no consequences because of the interest-free system. Compared to the conventional banking sector, Islamic banking institutions were not affected by the 
crisis. From this experience, the government realized that the Islamic financial system would become more significant for Malaysia as an alternative source of finance in the future.

${ }^{(19)}$ As far as the author's interviews conducted in 2004 in Malaysia found, the target was set as $8 \%$ in $2001,9 \%$ in $2002,10 \%$ in $2003,11 \%$ in 2004 etc.

(20) The first two banks are from Saudi Arabia and Kuwait respectively, the last one is a joint venture of Qatar, Saudi Arabia, and Kuwait.

${ }^{(21)}$ In the budget speech 2007, the government announced several tax measures; income tax exemption for 10 years given all Islamic banking institutions, takaful operators, foreign fund managers managing Islamic funds for foreign investors; stamp duty exemption related to Islamic financing for three years; personal tax relief for learning Islamic Finance in higher educational institutions including the International Centre for Education in Islamic Finance; tax deduction for expenses incurred in establishing an Islamic stock broking firm; and extension of period of tax deduction for expenses incurred in the issuance of Islamic products from 2008 to 2010 (Abdullah and Minister of Finance 2006). These treatments are expected to contribute to further development of the Islamic financial sector in Malaysia.

\section{REFERENCES}

1. Abdullah, bin Hj. Ahmad Badawi and Minister of Finance, The 2007 Budget Speech, Introducing the Supply Bill 2007 in the Dewan Rakyat, September 12006 (download from http://www.btimes.com.my/Current_News/BT/Friday/hold/budget07.pdf <last cited on April 27, 2007>).

2. Ahmad, Imad-ad-Dean, Riba and Interest: Definitions and Implications, paper presented at 22ne Conference of American Muslim Social Scientists, 1993 (download from www.globalwebpost.com/farooqm/study_res/i_econ_fin/imad_riba.htm <last cited on March 12, 2008>).

3. $\quad$ Ahmad, Mahmud, Judaism and Interest, Islamic Studies, Vol. 20, No. 1, pp. 48-81, 1981.

4. Bank Negara Malaysia, Annual Report 1982, Bank Negara Malaysia, Kuala Lumpur, 1983.

5. Bank Negara Malaysia, The Central Bank and the Financial System in Malaysia: A Decade of Change, Bank Negara Malaysia, Kuala Lumpur, 1999.

6. Bank Negara Malaysia, Monthly Statistical Bulletin, January, Bank Negara Malaysia, Kuala Lumpur, 2007.

7. BBC News, Islamic Institute Blesses Interest, November 18, 2002 (download from news.bbc.co.uk/2/hi/business/1488525.stm <last cited on July 10, 2008>).

8. Chandra, Muzaffar, Islamic Resurgence in Malaysia, Penerbit Fajar Bakti, Petaling Jaya, 1987.

9. Doi, Abdur Rahman I., Sharī'ah: The Islamic Law, Ta-Ha publishers, London, 1984.

10. Farooq, Mohammad Omar, The Riba-Interest Equivalence: Is There an Ijma (Consensus)?, 2006. (download from www.globalwebpost.com:farooqm/writings/islamic/r-i-consensus.html <last cited on March 10, 2008>).

11. Grossman, Andrew, Finding the Law: Islamic Law (Sharia), 2002 (download from http://www.llrx.com/features/islamiclaw.htm <last cited on March 13, 2008>).

12. Haron, Sudin and Bala Shanmugam, Islamic Banking System: Concepts and Applications, Pelanduk Publications (M), Petaling Jaya, 1997.

13. Iqbal, Munawar and David T. Llewellyn, Introduction, in Munawar Iqbal and David T. Llewellyn eds., Islamic Banking and Finance: New Perspectives on Profit-Sharing and Risk, Cheltenham: Edward Elgar, pp. 1-14, 2002.

14. Iqbal, Munawar and Philip Molyneuz, Thirty Years of Islamic Banking, Palgrave Macmillan, London, 2005.

15. Iqbal, Zamir and Abbas Mirakhor, An Introduction to Islamic Finance: Theory and Practice, John Wiley \& Sons (Asia), Singapore, 2007.

16. Horii, Kenzo, Dakwah Movement and Socio-political Changes of Rural Community in 1970s and 80s, (in Japanese), Asian Economies (Ajia Keizai), Vol. 28, No. 2, pp. 84-105, 1987.

17. Khan, M.A. Muqtedar, Mythology of Islamic Economics and Theology of East Asian Miracle, American Journal of Islamic Social Sciences, Vol.16, No. 4, pp. v-xvii, 1999.

18. Kuran, Timur, Islam and Mammon: The Economic Predicaments of Islamism, Princeton University Press, New Jersey, 2004.

19. Lewis, Mervyn K. and Latifa M. Algaoud, Islamic Banking, Edward Elgar, Cheltenham, 2001. 
20. Mason, Richard and Ariffin Omar, The 'Bumiputera Policy': Dynamics and Dilemmas, Kajian Malaysia, Vol. XXI, Nos. 1 \& 2, pp. 1-12, 2003.

21. Mohamed, Ariff, Islamic Banking, Asia-Pacific Economic Literature, Vol. 2, No. 2, pp. 46-62, 1988.

22. Nomani, Farhad and Ali Rahnema, Islamic Economic Systems, Zed Books, London, 1994.

23. Noorzoy, M. Siddieq, Islamic Laws on Riba (Interest) and Their Economic Implications, International Journal of Middle East Studies, Vol. 14, No. 1, pp. 3-17, 1982.

24. Rahman, Fazlur, Ribā and Interest, Islamic Studies, Vol. 3, No. 1, pp. 1-43, 1964.

25. Rashid, Salim, The Value of Time and Risk in Islamic Economics, 1983 (download from www.globalwebpost.com/farooqm/study res/i_econ_fin/srashid tmv.pdf <last cited on March 11, 2008>).

26. Securities Commission, Annual Report 2003, Securities Commission, Kuala Lumpur, 2003.

27. Shamsul, A.B., The Economic Dimension of Malay Nationalism: The Socio-Historical Roots of the New Economic Policy and Its Contemporary Implications, Developing Economies, Vol. 35, No. 3, pp. 240-261, 1997.

28. Torii, Takashi, Development Policies and Islamization Policy under the Mahathir Government in Malaysia, (in Japanese), Asian Studies (Ajia Kenkyu), Vol. 49, No. 1, pp. 19-36, 2003.

29. Venardos, Angelo M., Islamic Banking and Finance in South-East Asia: Its Development and Future, World Scientific Publishing Co. Pte. Ltd., Singapore, 2005

30. Zakariya, Man, Islamic Banking: The Malaysian Experience, in Mohamed Ariff ed., Islamic Banking in Southeast Asia, Institute of Southeast Asian Studies, Singapore, pp.67-102, 1988.

\section{WEB SITE}

1. Bank Negara Malaysia $\quad \underline{w w w . b n m . g o v . m y}$

\section{APPENDIX}

\begin{tabular}{ll} 
& Meaning of Shariah Concepts \\
\hline The Concept of Shariah & Meaning \\
\hline Wadiah Yad Dhamanah & savings with guarantee \\
Mudharabah & profit-sharing \\
Musyarakah & joint venture \\
Murabahah & cost plus \\
Bai' Bithaman Ajil & deferred payment sale \\
Bai' Dayn & debt trading \\
Ijarah Thumma al-Bai' & purchasing \\
Ijalah & leasing and subsequently purchasing \\
Qardhul Hassan & benevolent loan \\
Bai' as-Salam & future delivery \\
Bai' al-Istijrar & supply contract \\
Kafalah & guarantee \\
Rahnu & collateralized borrowing \\
Wakalah & nominating another person to act \\
Hiwalah & remittance \\
Sarf & foreign exchange \\
Ujr & fee \\
Hibah & gift \\
\hline
\end{tabular}

Source: Bank Negara Malaysia, web site (http://www.bnm.gov.my <last cited on April 20, 2007>) 